\title{
ISIKSUSEOMADUSTE SEMANTIKA
}

\section{Heili Orav}

Ülevaade. Artikli eesmärk on demonstreerida lähenemisviisi, mis opereerib ühe valdkonna sõnavaraga kontseptuaalsel tasandil. Valitud valdkonnaks siinses käsitluses on eestlaste isiksuseomaduste sõnavara. Materjal on kogutud suulise loetelukatse käigus ja kajastab eestlaste arusaama iseloomust ning iseloomujoontest. Eestlaste jaoks olulisi isiksuseomadusi - töökas, laisk, kade ja sõbralik - on analüüsitud freimisemantika teooria abil."

Võtmesõnad: freimisemantika, isiksuseomaduste sõnavara, välimeetod, omadussõnad, eesti keel

\section{Sissejuhatus}

Teoreetilised uurimused sõnadest, tähendustest, mõistetest ja nende omavahelistest seostest on oluliselt seotud ka praktiliste vajadustega, nt (arvuti)sõnastike koostamistega. Põhiküsimuseks on olnud ja on siiani: kuidas defineerida sõnu nii, et sõnaseletustes peegelduksid inimesele vajalikud maailmateadmised sõna tegelike kasutustingimuste kohta? Millised tunnused on olulised selleks, et keelekasutajad mõistaksid mingit sõna või väljendit ühtemoodi? Vaidlused nende küsimuste üle on aidanud sündida mitmel keeleteoorial, mis püüavad endas ühendada kontseptuaalset, leksikaal-semantilist ja leksikograafilist mõõdet, kuid mis oma arengus pole veel väga kindlate tulemusteni jõudnud. Käesolev artikkel püüab näidete varal osutada, mismoodi oleks võimalik esitada empiirilist materjali piisavalt põhjalikult eelkõige kontseptuaalsel tasandil. Kas siin pakutud esitusviis on küllaldane ja üldkasutatav, seda peaksid kontrollima edasised uuringud.

Mingi valdkonna sõnavara (klassikalises terminoloogias semantiliste väljade) uurimine on üks võimalikke meetodeid, mis seob üksiksõnad teatud tervikuks ja lubab formuleerida uuritava valdkonna semantilise struktuuri ning muuhulgas ka naiivteooriaid ja kultuurimudeleid. ${ }^{1}$ Traditsiooniliselt tehakse ühe keelekogukonna kultuurimudelid kindlaks sõnavara ja selles fikseeritud semantika kaudu,

* Artikkel on valminud Eesti Teadusfondi grandi nr 5534 toel.

${ }^{1}$ Eesti keeles on termini naiivteooria esimesena kasutusele võtnud Haldur Õim ja selle all mõeldakse piisavalt ulatuslikke ja kompleksseid teadmisstruktuure, mis liigendavad inimestele olulisi maailmapildi fragmente (Õim 1997: 258). 
sest suur osa maailmapildist on peidetud leksikaalsetesse tähendustesse (Apresjan 1992: 4). Antropoloog Roy D’Andrade on öelnud, et iseloomuliku kultuurimudeli paljastavad just inimese iseloomujoonte terminid (D'Andrade 1987).

Siinse artikli eesmärk ongi käsitleda ühe semantilise välja - inimese ja tema iseloomu - keelelis-semantilisi aspekte eesti keeles. Esile kerkivad järgmised küsimused. Millised on eesti keeles kõnelejate ja eesti keeles mõtlejate (proto)tüüpsed isiksuseomadused nende endi meelest? Milline "pilt" avaneb eestlastest, kui vaatleme isiksuseomadusi tähistavaid väljendeid eesti keeles? Kas ja kuivõrd saab iseloomusõnu semantiliselt/kontseptuaalselt analüüsida? Ja kui saab, siis kas freimisemantiline analüüs sobib isiksuseomaduste esitus-kirjeldusviisiks?

\section{Kuidas isiksuseomadusi uurida}

Francis Galton (1822-1911) oli väidetavalt esimene, kes tuli 1884. a selle peale, et võtta kätte sõnaraamat ja kirjutada sealt välja omadussõnad, mida inglise keeles kasutatakse inimese iseloomustamiseks (Allik 2003). Saksa uurijat L. Klagest (1926) aga peetakse esimeseks, kes sõnastas selgelt teoreetilise põhjenduse, miks keele uurimisest võib inimese mõistmisel kasu olla. See on psühholoogias tuntuks saanud leksikaalse hüpoteesi nime all:

Kõik sotsiaalses lävimises olulised omadused talletuvad aja jooksul keeles; mida silmatorkavama ja olulisema omadusega on tegemist, seda suurem on tõenäosus, et selle omaduse tähistamiseks on keeles omaette sõna. (Goldberg 1993, John 1990)

Psühholoogias jätkuvad isiksuseomaduste ${ }^{2}$ leksikaalsed uuringud, et leida teaduslikku raami inimest iseloomustavate omaduste organiseerimiseks. Ja kuigi erakordsete ja ainult ühele inimesele kuuluvate loomuomaduste analüüs võib olla väga huvitav, on siinses artiklis huviobjektiks siiski keel, keelelised vahendid ja keeleline väljendus, mida kasutatakse inimese iseloomustamiseks, mitte otseselt inimene ise.

Tavapäraselt mõistetakse isiksuse all eelkõige iseloomu ehk karakterit - st kui me mõtleme mõne inimese peale, siis me mõtleme muuhulgas ka tema iseloomu peale. Ei ole kujuteldav, et mõni inimene oleks ilma iseloomuta, iseloomujoonteta. Sellele viitab ka levinud arusaam, et iseloomu omamises on midagi märkimisväärset. Näiteks võib kellegi kohta öelda: Ta on iseloomuga inimene! või Ise alles kolmeaastane, aga juba näitab iseloomu!. Seega osutab keelekasutus, et mõiste ISELOOM on midagi, millega peab arvestama, olgu siis positiivses või negatiivses mõttes.

Selge on, et iseloomu kategooria keeles on inimestele loomupäraselt tuttav. Seda tõendab iseloomujooni tähistavate sõnade suur hulk suvalises keeles ja asjaolu, et inimesed oskavad neid kasutada nagu kõiki teisigi sõnu keeles ning otsustada, kas mingi kasutus on keeleliselt (sisuliselt) korrektne või mitte. Ilma keeleliste vahenditeta suudaksid inimesed küll näha üksteise käitumismustreid, kuid nad poleks neist teadlikud (nt inimene võib ju aus olla, kuid sellel pole mingit moraalset ega muud väärtust, kui ühiskond seda keeleliselt ära ei märgi, seda ei nimeta). Seega on iseloomujoonte sõnavara ka peegelpilt ühe kogukonna

${ }^{2}$ Isiksuseomadused on laiemas mõttes kõik inimese kohta käivad omadused: iseloomujooned, välimus, oskused jne. Kitsamas mõttes mõeldakse nende all ainult iseloomujooni, nii on ka siinses töös. Isiksuseomadusi, loomuomadusi, iseloomuomadusi ja iseloomujooni käsitatakse sünonüümidena. 
aktsepteeritavatest ja taunitavatest käitumisnormidest, omadustest, väärtustest ning arusaamadest.

Teatud valdkonna sõnavara võib kindlaks teha mitmel moel. Iseloomujooni tähistavaid sõnu ja väljendeid on kogutud kahel viisil:

- otsitakse olemasolevatest andmestikest, nt sõnastikest;

- $\quad$ keelekasutajaid küsitletakse vahetult, välimeetodiga.

Esimene annab ajatu pildi - arvesse tulevad kõik asjakohased sõnad ja väljendid, mis on sõnastikes olemas ja on keelde kogunenud määratlemata aja jooksul. See on hea meetod n-ö fundamentaalse iseloomuga uurimuste puhul ja seda on kasutatud ka isiksusepsühholoogias. Selle lähenemise häda on eelkõige selles, et keegi peab otsustama, millised sõnad käivad iseloomu kohta ja millised mitte. Teine meetod võimaldab saada ülevaate keelekasutajate jaoks aktuaalsest, tegelikus käibes olevast sõnavarast. Ka sel meetodil on omad puudused: isegi kui inimesel on üsna selge arusaam iseloomujoontest, ei pruugi talle soovitud väljendid kohe meelde tulla, küsitletav võib iseloomujoont tähistava sõna asemel kirjeldada pikalt kellegi käitumisviisi või selle tagajärgi. Keelekasutuse seisukohalt on välimeetod siiski palju informatiivsem kui sõnastik.

Siinses töös on rakendatud välimeetodit, täpsemalt välimeetodil läbi viidud loetelukatset (vt ka Sutrop 2001). Küsitluse läbiviimisel on järgitud tulemuste usaldusväärsust tagavaid nõudeid (küsitletavate valik, küsimuste samasus jm). Küsitluste kaudu saadud materjal võimaldab välja selgitada "praeguse eestlase" iseloomukäsitust, määratleda omaduste olulisust, kaalu ning hinnangulist aspekti.

\section{Isiksuseomaduste sõnavara eesti keeles}

Ajavahemikus sügis 2003 kuni talv 2004 küsitleti 100 eestlast (50 meest ja 50 naist) vanuses 14-90 eluaastat.

Küsitlus koosnes 4 allülesandest, kus paluti nimetada omadusi: 1) üldiselt inimese iseloomu kohta, 2) sümpaatse/ebasümpaatse tuttava inimese iseloomu kohta, 3) eestlase iseloomu kohta ning 4) iseenda iseloomu kohta.

Neile küsimustele anti nimetamiskatses kokku 5461 vastust, milles enamik sõnu või väljendeid kordus. Sõnaliigiliselt nimetati iseloomujoonte tähistajatena peamiselt omadussõnu, harvem ka nimisõnu (223 korral) ja verbifraase (26 korral). Välimeetodiga kogutud materjali õnneks ja õnnetuseks on paljud erilised sõnad ja väljendid, mida traditsiooniliselt ei kasutata inimeste iseloomustamisel (nt rakenduslik, saddhvalik, Kaarel Tarand, tüüpiline sõnn, pole kõige hullem, õhuline jms) - siinses töös on kõrvale jäetud 90 sedalaadi väljendit, sest nende seotus iseloomuga on ebaselge. Sõnavara, millega uurimuses oli võimalik (semantiliselt) opereerida, sisaldab 1271 erinevat sõna või väljendit.

Nimetamiskatses sagedamini nimetatud sõnad peaksid tähistama antud kultuuriruumis olulisi iseloomuomadusi (Orav, Vainik 2005). Küsitlusel saadud materjalis oli kõige sagedamaks iseloomujooneks töökus - omadussõna töökas nimetati kokku 150 korral. ${ }^{3}$ On selge, et oma suure sageduse tõttu näitab töökus eestlase prototüüpseimat iseloomujoont ja moodustab eestlaseks olemise naiivteooria keskse elemendi (Orav, Vainik 2005).

\footnotetext{
${ }^{3}$ Sagedusstatistika erineb allülesannete kaupa. Esimese ülesande tulemusena iseloomustati inimest üldiselt kõige sagedamini omadustega: sõbralik, abivalmis, kuri, lahke jne; tuttavat inimest: abivalmis, enesekeskne, sôbralik, valelik, tark, lahke jne; eestlast: töökas, kade, kinnine, edasipüüdlik jne; iseennast: laisk, sôbralik, töökas, abivalmis jne.
} 
Töökale järgnesid muud omadussõnad (number sõna taga näitab nimetamise kordi): sõbralik 110, tark 88, kade 86, abivalmis 85, laisk 78, kinnine 70, aus 60, lahke 60, kuri 51, edasipüüdlik 47, rahulik 47, tagasihoidlik 47, hea 45, õel 35, rumal 34, ahne 33, rõõmsameelne 33, egoist(lik) 32, hooliv 32, lõbus 32, julge 32, jonnakas 29, mõistev 29 jne. See loetelu heidab valgust muudelegi inimkäitumise ja -omaduste aspektidele, mida eestlased peale töökuse kaasinimeste juures märkavad ja oluliseks peavad.

Kuna antud artikli maht ei võimalda teha semantilist analüüsi kõigi eestlaste poolt nimetatud loomuomaduste kohta, käsitlen lähemalt ainult nelja iseloomujoont - töökas, laisk, kade ja sõbralik. Näitlikustamiseks sobivad need loomuomadused kõige paremini esiteks seetõttu, et need on küsitletute arvates olulised omadused, mida näitab statistiliselt ka nende ülisuur esilduvus nimetamiskatses. Teiseks esindavad need omadused erinevat tüüpi ning erinevaid aspekte sisaldavaid iseloomujooni. Nii on sõbralikkus inimese välises käitumises avalduv kaaskodanike tegevusega seotud ehk sotsiaalne omadus, kadedus inimese sisemist hoiakut teiste suhtes tähistav omadus, millest kaasinimesed arugi ei pruugi saada. Töökus ja laiskus avalduvad jälgitavas inimtegevuses, kus teiste inimeste osalemine pole niivõrd oluline, kuigi neid mõisteid kellegi kohta öelduna saab kasutada ainult võrdluses kaasinimestega.

Enne nende omaduste analüüsi juurde asumist mõni sõna uurimuse teoreetilistest alustest, milleks siin on valitud freimisemantika.

\section{Freimisemantika}

Püüdlused keele semantilise struktuuri esitamiseks on universaalsed: töötada välja kindel esitusviis, semantiline keel, mille abil võiks kirjeldada mis tahes sõna vm keeleüksuse tähendust (Õim 1974: 146) ja milles kajastuksid keelekasutajate maailmateadmised. Alternatiiviks sõnaseletuste traditsioonile pakkus Charles Fillmore välja freimid. Tema tsiteerituim näide keeles peituva kultuurimudeli kohta on vanapoisi mõiste, kus ta leidis, et tavapärased vanapoisi definitsioonid sõnastikes on ebaadekvaatsed (Fillmore 1975), sest osa inimeste teadmistest selle sõnaga seoses on küll sõnaraamatu-tüüpi ('mitte abielus täiskasvanud mees'), aga osa on üldised maailma- ning kultuuriteadmised abielust ja vallalisusest (nt teadmine, et munka ei saa vanapoisiks nimetada). Teine sama autori tüüpnäide on ostma. Kui tavapärased seletussõnaraamatud annavad sellele paarisõnalise seletuse, siis maailmateadmistele tuginedes tuleb esitada kogu situatsioon: kui keegi ostab, siis keegi müüb; müüb midagi, millel on ostjale väärtus; selle väärtuse eest ostja maksab müüjale midagi jne (Atkins, Fillmore 1992). Samasugused kirjeldused peavad põhimõtteliselt olemas olema igasuguste tegevuste, situatsioonide, omaduste jm tunnuste kohta. Ch. Fillmore'i järgi sobiksid selliseks kirjeldusmeetodiks kõige paremini freimid (Fillmore 1985).

Freimi põhiidee on selles, et freim kui semantiline struktuur on kontseptuaalne struktuur, mis ühendab (ei ole täpne öelda "sisaldab") enamasti tervet hulka sõnu, lekseeme, millel on ühine alussituatsioon, alusstruktuur, mille osi nad esitavad, ja kus on fikseeritud objekti, tegevuse, situatsiooni vm määravad tunnused ja nende võimalikud väärtused. Ühte situatsiooni kirjeldavasse freimi kuuluvad sõnad võivad olla üpris juhuslikud, ebapüsivad, ka idiosünkraatilised, samal 
ajal kui vastav "tüüpsituatsioon" - freim - ise on hoopis universaalsem ja püsivam. Kuivõrd freimide esitamiseks on selle mõiste kasutuselevõtust alates pakutud välja ka mitmesuguseid vormilisi struktuure, siis võidakse freimi all mõnikord mõista ainult vormilist struktuuri (vt nt sellele temaatikale pühendatud ajakirja Quaderni di Semantica erinumbrit (1985), eriti Fillmore 1985, Saluveer, Õim 1985; Saluveer, Õim 2002; samuti Fillmore 1986).

Kuna freimi võib käsitleda piisavalt üldisena, mis heidab lisaks sõnakasutusele valgust ka maailma- ja kultuuriteadmistele, siis võimegi selle kaudu jõuda naiivteooriateni, kus teooriana käsitletakse mingi sotsiaalse grupi ühises kasutuses olevat kognitiivset skeemi (D’Andrade 1987: 112). Mõlema - freimide ja naiivteooriate - puhul püütakse esitada lihtsustatud skemaatilist maailma, milles avalduvad prototüüpsed sündmused.

Kuigi freimisemantilise analüüsi põhiideed on pärit 1970-ndatest aastatest (Fillmore 1975), pole freime sõnatähenduste analüüsimiseks laialdaselt kasutusele võetud - uurimusi selle kirjeldusmeetodi efektiivsusest ja parimast esitusformaadist alles tehakse. Vajadus uute sõnatähenduste kirjeldusmeetodite järele on aga suur (nt (arvuti)sõnastike koostajatel). Parim näide, kus freime kasutatakse, on FrameNeti ${ }^{4}$ projekt, kus esialgu ainult vähestele sõnadele on püütud teha põhjalikku freimisemantilist analüüsi, kuna ülejäänute puhul on esitatud ainult algseks analüüsiks vajalikud freimielemendid. Ka siinses artiklis on piirdutud pigem võimalike freimiskeemide kui täieliku analüüsiga.

\section{Eestlaste iseloomujoonte freimisemantiline analüüs}

Iseloomujoonte kirjeldamiseks tuleb püüda koostada n-ö omadusfreime. Omadusfreimid erinevad muutumis- või tegevusfreimidest, kus on fikseeritud situatsiooni algus, muutus ja lõppseisund. ${ }^{5}$ Pigem on nad suguluses seisundifreimidega, kus määravad elemendid on seisundis olija, seisund ja selle võimalikud mõjud teistele situatsioonis osalejatele. Viimast komponenti ei pruugi seisundifreimides alati eksisteerida, aga iseloomufreimides oleks see ilmselt obligatoorne. Füüsilise seisundi mõttes võib keegi olla püsti või pikali, ilma et see kedagi puudutaks, kuid kade (või sõbralik) ei saa inimene olla, ilma et see poleks seotud teiste inimestega. Seos teistega on olemas kas või ainult selles mõttes, et inimese iseloomustamisel on alati tegu hinnanguga, mitte inimtegevust kirjeldava väljendiga.

Seda, et iseloomujooni nimetavate sõnade sisuga seostub valdavalt hinnanguline aspekt, kinnitavad ka Moonja Kim ja Seymour Rosenberg (1980), kes väidavad, et "iseloomujooni tähistavad sõnad on mitmekesised moodused inimeste hindamiseks." Hinnang tuleneb käitumise põhjal antavast klassifitseeringust, mida tuleb mõista seoses taustsündmustega ja sotsiaalsete ootustega (Orav, Vainik 2005). On ka märgitud, et hinnangulisus on inimkäitumise kirjeldamisel nii sügav ja hävitamatu, et mingi protsess ei suuda hinnanguvaba süsteemi luua (D'Andrade 1985: 332). Seega võib väita, et keskmine keelekasutaja käsitab hinnangulisust loomuliku ja haakuva osana üldisest iseloomustamisprotsessist. Nii ongi isiksuseomaduste juures üldkehtiv komponent - HINNANG - juba fikseeritud.

Enne detailse analüüsi juurde asumist tuleb leida ja osutada muudelegi ühistele elementidele, mis eristavad isiksuseomaduste valdkonda kõigist ülejäänud inim-

\footnotetext{
${ }^{4}$ Vt http://framenet.icsi.berkeley.edu/ (26.10.2005). FrameNeti projekti juhib freimisemantika alusepanija Charles Fillmore.

5 Tegevusfreimidest annavad ülevaate nt Orav 1998, Pükke 2005.
} 
tegevuse või -omadustega seotud valdkondadest. Freimisemantilise esituses on kõik komponendid esitatud tunnuste struktureeritud kogumina, mille põhitasandid on lemma, freimielementide grupp ja situatsiooni klassifikatsioon (lisainfo).

Järgnevas määratletakse omaduste freimiskeemides kõik olulised freimielemendid (edaspidi FE1, FE2 jne) - komponendid, mis sisalduvad kogu käsitletava valdkonna sõnavara tähendustes.

Nagu nimetatud, esineb selle sõnavara freimisemantilisel analüüsimisel alati HINNANG, mis on primaarne ja millega on seotud järgmised eri rolli kandvad elemendid:

FE1 roll: AUTOR - hinnangu andja. See on loomuomadusfreimi puhul absoluutselt üldine, kuna kõik iseloomusõnad on põhimõtteliselt hinnangusõnad. Hinnangu autoriks loetakse ka iseennast - "enda" suhtes saab olla nii- ja naasugune (nt murda endale antud sõna).

FE2 roll: OBJEKT1 - hinnangualune isik, keda mingi keelelise väljendiga iseloomustatakse ja kelle roll muutub hindamise käigus AGENDIKS (A), sest hinnatakse tema:

- otsuseid, arvamusi, hoiakuid, emotsioone;

- tegevusi ehk käitumist;

- tegevuse all-liigina suhtlust ja selle komponente (nt suhtluse sisu, suhtluse laad, teema).

FE3 roll: VÄÄRTUS - antud hinnangu laad: negatiivne või positiivne.

Olulisteks aspektideks inimese iseloomustamise situatsioonis võivad osutuda ka muud freimielemendid, nagu PÕHJUS, TAGAJÄRG, OBJEKT2 (kellele AGENDI tegevus, hoiak vm on suunatud). Neid komponente saab asendada konkreetsete tähendusstruktuuridega, mis tähendab, et nende komponentide kasutamistingimuste teadmine ongi nende (omadus)sõnade tähenduste teadmine. Näitlikustamiseks sobivad sõnad ahne ja omakasupüüdlik, mida sõnastikus esitatakse kui sünonüüme (nt Filosofti tesaurus) ${ }^{6}$. Mõlemad sõnad on küll seotud kasusaamise aspektiga (PÕHJUS), kuid ahnuse puhul ei ole oluline teiste inimeste olemasolu ega nende tegevus - ahne saab inimene olla ka üksi rabas marju korjates, kuid omakasupüüdlik on olulisel määral seotud teiste inimestega (OBJEKT2), kelle arvel endale kasu hankida püütakse. Seega on freimisemantikale omane eelkõige idee, et tähendusstruktuur tuleb jagada osadeks, mida on võimalik süsteemselt esitada.

Järgnevalt püüan visandada freimiskeeme eestlast erinevatest vaatenurkadest kirjeldava nelja loomuomaduse kohta, alustades kõige sagedamini välja toodud omadusest - töökas.

\subsection{Töökas}

See inimese isiksuseomadus väärib erilist tähelepanu, kuna osutus kõige olulisemaks omaduseks eestlaste jaoks - seda näitas ülisuur esiletulek loetelukatses.

Mida me mõtleme, kui iseloomustamekedagi töökana? Üks on kindlasti kõnealuse inimese tegevus: inimene on töökas, kui ta valmistab, loob, organiseerib midagi kas üksinda või koos teistega - igal juhul ei ole teiste inimeste olemasolu ega nende tegevus määrav. Seega kellegi nimetamine töökaks on eelkõige inimest omaette kirjeldav mõiste, mille puhul interaktsioon kaasinimestega võib, kuid ei pruugi toimuda.

${ }^{6}$ Vt www.filosoft.ee (26.10.2005). 
Lähemalt mõistet TÖÖKUS analüüsides selgub, et sõna töökas vastandiks peetakse tavakõnes sõna laisk, mis küll ei osutu ainutõeks, sest keelekogukond on hakanud kasutama uusi sõnu - ületöötav ja töönarkomaan, mis tähistavad töötamisega liialdamist, äärmuslikkust töötegemisel ja on, nagu ka laisk, negatiivse märgiga omadused (Orav, Vainik 2005). Omaduste mõistmine ongi valdavalt organiseeritud vastanditega, mis leksikaalselt väljenduvad antonüümiasuhtes, kuigi loomulik keel pole selles osas järjepidev. Võib-olla sellepärast tundubki vastandpaari töökas-laisk ülisuur esilduvus loetelukatses üsna loomulik, sest omaduse töönarkomaan vastandumine töökale on suhteliselt uus ja hiljutine nähtus meie maailmapildis.

Eelnevat arvestades näeks TÖÖKUSE freimiskeem välja järgmine.

\section{TÖÖKUS}

Freim esitab prototüüpse situatsiooni (keegi (A) on töökas, usin vm), kus hinnatakse A tegevust.

A on töökas, kui:

teeb, valmistab, loob, organiseerib vms (seos TEGEVUSE freimiga, kus on fikseeritud situatsiooni algus, muutus ja tulemus) hindaja arvates kvantitatiivselt palju tegevusi, oodatust rohkem tegevusi või kellegi teisega võrreldes rohkem tegevusi.

VÄÄRTUS (AUTORI hinnang): positiivne.

TÖÖKUSE tähendusvälja ehk freimiga saab loetelukatse tulemustest lisaks sõnale töökas ühendada ka muid sõnu ja väljendeid. Nii nimetati:

- negatiivse VÄÄRTUSEGA omadusi: laisavõitu, laisk, mugavust armastav, mugav;

- positiivse VÄÄRTUSEGA omadusi: tööarmastaja, tööhimuline, töökas, pole laisk, usin, tragi, virk, töörügaja;

- negatiivse VÄÄRTUSEGA omadusi: töönarkomaan, liiga töökas, rabaja, töörügaja, ületöötanud, ületöötav, koormatud.

Küsitavaks jääb töörügaja hinnanguline märk, autori arvates võib seda kasutada nii negatiivse kui positiivse hinnanguna.

Lisaks mainitud omadustele on TÖÖKUSEGA võimalik seostada ka suurt hulka muid erinevaid iseloomuomadusi, mis võivad olla (ja tihti ongi) olulised ning vajalikud töö tegemise juures (visa, jonnakas, vastupidav, sitke, konkreetne, ratsionaalne, kohusetundlik, osav, korrektne jm). Samuti kuuluvad siia inimeste teatud oskusi tähistavad sõnad, nagu professionaalne, koostöövalmis, süsteemne, organisaator jm, ning saavutustele suunatud hoiakuid ja käitumisjooni tähistavad sõnad, nagu edasipürgiv, edasipüüdlik, ambitsioonikas, auahne, karjerist, eesmärgikindel jt. Kuid kõigi eelnimetatute puhul lisanduvad freimiskeemi(de)sse teistsugused komponendid: seos oskus(t)ega, põhjus(t)ega vms, mis peavad freimis kajastuma ja mis eristavadki neid mõisteid üksteisest. 


\subsection{Laisk}

Isiksuseomaduste loetlemisel ilmnes tendents, kus väga sageli nimetati eestlast töökaks ja iseennast laisaks. Võib-olla viitab enese hindamine laisaks liigsele enesekriitikale, kus kõne all olevat eestlast nähakse pigem kauge eeskujuna või vähemalt töötegemise suhtes usinamana kui iseennast? Kust läheb piir tööka ja laisa vahel? Äsja nägime, et eestlaste omakuvandis domineeriv töökus on mõneti vastuokslik, sest ta on eestlaste keeleruumis läbi põimunud hinnangutega nii liigse töötegemise (töönarkomaan) kui ka vähese töötegemise (laisk) kohta ja tuleb tõdeda, et nende tähenduspiiride tajumine jääbki individuaalse kogemuse või tunnetuse tasemele.

Mõiste LAISK tähendusaspektid erinevad mõneti sellest, mis olid olulised TÖÖKA puhul. Kui tööka defineerimisel on suhteliselt selge, mida inimene peab tegema selleks, et teda saaks nimetada töökaks, siis laisa puhul on olukord teine. Näiteks võime arutleda järgmiselt: mille poolest erineb või sarnaneb laisk, hooletu, muretu ja kohusetundetu inimene? Kõiki neid ühendab see, et hinnangualune inimene jätab midagi tegemata. Laisk võib olla ka see, kes täidab kõik talle pandud kohustused (on kohusetundlik), aga teatud situatsioonides jätab teatud asjad tegemata. See on võimaluse kasutamine mitte teha siis, kui ei pea, aga lisaks jääb muidugi ka võimalus, et ei tehta ka neid asju, mida peab. Siin on ainult küsimus - miks? Millal selline inimene on laisk, millal hooletu, millal kohusetundetu? Kõik need väljendavad, et kellegi arvates keegi teeb vähem (või ei tee asju, mida peaks ja saaks teha) kui mõni teine. Siit jõuame järeldusele, et laiskus on eelkõige küsimus mittetegemise põhjustest, mis peavad seega freimisemantilises kirjelduses esinema.

Teiste nimetatud omadustega on mingi tegevuse mittetegemise põhjused eristatavad järgmiselt: laisk $\rightarrow$ põhjus on "ei viitsi”; hooletu $\rightarrow$ "ei hooli”; muretu $\rightarrow$ "ei muretse" tagajärgede või järgneva pärast; kohusetundetu $\rightarrow$ "ei pea" kohustusi tähtsaks.

Mis aga tähendab omakorda "ei viitsi"? "Ei viitsi" = ei teki tahtmist, huvi vms ehk tänapäeva terminoloogias "ei teki (sisemist) motivatsiooni”. Ükski tegu ei sünni ilma sisemise tahteta (ingl intention). Kui seda ei teki, siis "ei viitsi" - see ei ole küll ammendav, aga on piisav põhjus.

\section{LAISKUS}

Freim esitab prototüüpse situatsiooni (keegi (A) on laisk, mugav vm), kus hinnatakse A tegevust.

A on laisk, kui:

a) vaadeldavas situatsioonis peaks hindaja arvates A tegema ootuspäraselt mingi hulga tegevusi;

b) A ei tee neid tegevusi või hindaja arvates mitte kogu hulka;

c) A ei viitsi neid tegevusi teha (põhjus).

VÄÄRTUS (AUTORI hinnang): negatiivne. 


\subsection{Kade}

Lisaks töökusele peetakse tänapäeva eestlase prototüüpseks iseloomujooneks ka kadedust. Võrdluseks võiks tuua kümne aasta taguse Hille Pajupuu uurimuse, milles tuli välja, et eestlased olid tollal enesest heal arvamusel - negatiivseteks omadusteks peeti eelkõige kinnisust ning külmust, kuna kadedust isegi ei nimetatud (Pajupuu 1994). Sama autor on siiski oma hilisemas uurimuses kinnitanud kadeduse suurt osatähtsust eestlaste iseloomustamisel, mille põhjuseks olevat meie majanduselu muutused (Pajupuu 2005). Seega tundub, et kadedus on eestlastele suhteliselt hiljuti oluliseks muutunud omadus.

Iseloomujoon kadedus avaldub mitte niivõrd inimese väliselt nähtavas tegevuses, kuivõrd pigem teistele suunatud hoiakutes, arvamustes või hinnangutes, mida, nagu öeldud, võivad jätta kaasinimesed märkamata. Ei saa unustada tõsiasja, et meie vaikimisi toimivate sotsiaalsete käitumisnormide järgi, kus teiste heaolu üle pahameele tundmine on taunitav, eeldataksegi, et inimene hoiab oma kadedust välisilma eest varjatuna. Samas on kadedus seotud suhteliselt intensiivse tundelaenguga, mille varjamine võib mõnele inimesele üle jõu käia ja esile kutsuda soovi väljendada oma emotsioone, arvamusi, hoiakuid vms. Kuid sel juhul on tegemist pigem inimkäitumist suunava põhjusega.

Eestlaste teadvuses on kadedusel kaks alltähendust.7 Üks neist on mõistel KADE1 - olemuselt intrapersonaalne omadus, mis on suunatud teistele inimestele (ja nende omandile) kas otseselt või varjatult. Selles tähenduses on kade seotud ka omadustega nagu armukade ja kiivas, mida tuleks käsitleda alammõistetena, kuigi traditsioonilistes leksikaal-semantilistes käsitlustes puudub omadussõnadel hierarhiline suhe (Gross jt 1990; Orav 2000, 2002).

KADE2, mille vastandiks on lahke ja lähisünonüümideks ihne, kitsi, koi, näib olevat rohkem interpersonaalne omadus, st eeldab interaktsiooni teistega.

Tänapäeva eestlase jaoks näib KADE1 olevat omadusena primaarsem ja aktiivsem. Seda arusaama toetavad eelkõige sellele tähendusele osutavad iroonilised ütlused, nagu eestlase parim toit on teine eestlane või keegi uurib naabri rahakotti, mida ka loetelukatses nimetati. Eelnevat arvestades ongi siin tähelepanu all KADE1.

\section{KADEDUS}

Freim esitab prototüüpse situatsiooni (keegi (A) on kade), kus hinnatakse A hinnanguid, arvamusi, hoiakuid teiste inimeste suhtes või A suhtlust (mida räägib sel teemal).

A on kade, kui:

tunneb meelehärmi, pahameelt vms kellegi isiku(te) peale (sest võib soovida endale samuti saavutusi, heaolu vms); selle kaudu seos:

(negatiivse) EMOTSIOONI freimiga (Ta tunneb kadedust.); emotsiooni OBJEKTIGA, mis tavaliselt on isik(ud) ja konkreetsemalt tema saavutused, heaolu vms (Tema ametikoht ja kõrge palk ei andnud kadedatele hingerahu.).

(Võimalusel või kui peab vajalikuks:

A väljendab emotsiooni või arvamust (= kuidas hindab); selle kaudu tuleb sisse SUHTLUSE freim või veel üldisemalt TEGEVUSE freim. ${ }^{8}$ )

VÄÄRTUS (AUTORI hinnang): negatiivne.

\footnotetext{
${ }^{7}$ Ka EKSS-is eristatakse kahte kadedust, kus üks on teise alltähendus: KADE1 - teiste saavutuste, edu, heaolu vms puhul meelehärmi tundev ning kõike endale ihkav; seda meelelaadi väljendav? KADE2 - midagi ainult endale hoida tahtev, millegagi kokkuhoidlik, säästlik, kitsi.

${ }^{8}$ Tegevuse all võib mõelda ka näiteks näogrimasse vm kehaga edasiantavaid märke.
} 


\subsection{Sõbralik}

Erinevalt mõistest KADE, kus inimese aktiivne tegevus pole tingimata eeldus, on SÕBRALIKKUS hoopis teist tüüpi mõiste. Sõbralikkus on sotsiaalne omadus, mis on nähtav ja kuuldav inimese (suhtlus)tegevuse kaudu. Sel juhul on hinnangu objektiks eelkõige inimese suhted ja suhtlemine teiste inimestega.

Asjaolu, et inimene saab sõbralik olemist teeselda, on inimpsüühika huvitav nähtus, sest näiteks eelmise omaduse - kadeduse - puhul pole see üldjuhul võimalik. Samas pole mingit vajadust teeskluse võimalikkust eraldi kirjeldada. Seega on oluline veelkord rõhutada, et freimisemantika annab meile vahendid selleks, et saaksime kirjeldada tüüpilist situatsiooni, kus eeldatakse fikseeritud tunnuste kehtimist.

\section{SÕBRALIKKUS}

Freim esitab prototüüpse situatsiooni (keegi (A) on sõbralik, armastusväärne jne), kus hinnatakse A tegevust:

a) mil viisil käitub partneri(te) suhtes;

b) sh kuidas, mil viisil räägib partneri(te)ga suheldes.

A on sõbralik, kui:

a) naeratab, vaatab otsa vms, seos TEGEVUSE freimiga + POSITIIVSUSE freimiga (ei eelda verbaalset suhtlust);

b) räägib meelsasti ja heatahtlikult; selle kaudu tuleb sisse SUHTLUSE freim + POSITIIVSUSE freim.

VÄ̈̈RTUS (AUTORI hinnang): positiivne.

SÕBRALIKKUSE freim ühendab endas ka muid sõnu iseloomuomaduste leksikonist:

- $\quad$ positiivse VÄ̈̈RTUSEGA omadused: sõber, armastusväärne, saan kõigiga hästi läbi, lahke;

- negatiivse VÄ̈̈RTUSEGA omadused: ebasõbralik, mitte (väga) sõbralik, tõrjuv, tõrges, vältiv, põgenev, eemaletõmbuv, trotslik.

Sõbralikkuse määr on ilmselt tingitud inimühiskonna ja koostöö normidest: kui keegi poleks mitte kunagi kellegi vastu sõbralik, ei oleks ka koostöö võimalik.

\subsection{Freimisemantilise analüüsi kokkuvõtteks}

Analüüsitud nelja omaduse olulised aspektid ilmnevad kokkuvõtvalt selles, mida agendi juures hinnatakse:

1) tegevust (töökas, laisk, sõbralik),

2) (tegevuse üht alaliiki) suhtlust (sõbralik, kade),

3) otsuseid, arvamusi, hoiakuid (kade), ja milline hinnang - positiivne või negatiivne - neile antakse.

Omaduste freimisemantilise analüüsi kohta võib täheldada, et iseloomumõistete tähenduslike iseärasuste analüüsimisel on üpris raske leida kõiki relevant- 
seid semantilisi rolle ja aspekte. Möönan, et otsustus freimielementide valiku ja olulisuse üle mõne loomuomaduse mõiste juures võib tugineda tähenduste subjektiivsele mõistmisele. Seega ei pruugi loomuomaduste analüüsimisel freimisemantika olla alati piisavalt täpne ja üheselt mõistetav ega kajastada inimpsüühika ja -käitumise kogu nüansirikkust.

\section{Kokkuvõte}

On hea meeles pidada, et loomulikus keeles olevad iseloomusõnad on loonud inimesed ise ja inimeste jaoks, kuna inimeste peamine vajadus on kindlaks teha, kuidas reageerida teistele inimestele - kas läheneda või vältida, imiteerida või parandada vm. Inimest iseloomustavad sõnad loomulikus keeles sobivad hästi nendeks eesmärkideks (D’Andrade 1985: 332).

Eelnev oli vaid põgus arutelu sellest, mis on eestlaste jaoks olulised iseloomuomadused ja milliseid arusaamu ning aspekte need mõisted endas kätkevad. Uurimusest selgus, et tüüpiline eestlane on mitmekülgne ja mõneti vastuokslik, sest eestlaste endi poolt nimetatud sagedasemad loomuomadused olid töökas, sõbralik, tark, kade, abivalmis ja laisk, millest siinses artiklis käsitleti ainult nelja omadust. Seda, missugust rolli nimetatud iseloomujooned "keskmise eestlase portrees" etendavad ja mis roll omistatakse loomuomadustele vastavas kultuuris tervikuna, jätab autor lugejate otsustada.

\section{Kirjandus}

Allik, Jüri 2003. Isiksus ja seadumused. - Isiksusepsühholoogia. Toim J. Allik, A. Realo, K. Konstbel. Tartu Ülikooli Kirjastus, 23-65.

Apresjan, Jurij D. 1992. Systemic lexicography. - Euralex-92. Proceedings. Part I. Tampere, $3-16$.

Atkins, B. T. Sue; Fillmore, Charles 1992. Towards a Frame-based Lexicon: the Semantics of RISK and its Neighbors. - Frames, Fields and Contrasts: New Essays in Semantic and Lexical Organization. Ed. by A. Lehrer, E. F. Kittay. Lawrence Erlbaum Associates. Hillsdale, New Jersey, 75-102.

D’Andrade, Roy G. 1985. Character Terms and Cultural Models. - Directions in Cognitive Anthropology. Ed. by Janet W. D. Dougherty. University of Illinois Press, 321-342.

D’Andrade, Roy G. 1987. A Folk Model of the Mind. - Cultural Models in Language and Thought. Ed. by D. Holland, N. Quinn. Cambridge: Cambridge University Press, 112-148.

EKSS = Eesti kirjakeele seletussõnaraamat 1992, II köide, 1. vihik.

Fillmore, Charles 1975. An alternative to checklist theories of meaning. - Papers from the First Annual Meeting of the Berkeley Linguistics Society, 123-132.

Fillmore, Charles 1985. Frames and the Semantics of Understanding. - Quaderni di Semantica 6, 222-254.

Fillmore, Charles 1986. "U”-semantics, second round. - Quaderni di Semantica 8, 49-58.

Filosoft. www.filosoft.ee (26.10.2005).

FrameNet. http://framenet.icsi.berkeley.edu_(26.10.2005).

Goldberg, Lewis R. 1993. The Structure of Phenotypic Personality Traits. - American Psychologist 48, 26-34. 
John, Oliver P. 1990. The "Big Five" factor taxonomy: Dimensions of personality in the natural language and in questionnaires. - Handbook of personality: Theory and Research. Ed. by L. A. Pervin. New York: The Guilford Press, 66-100.

Kim, Moonja Park; Rosenberg, Seymour 1980. Comparison of Two Structural Models of Implicit Personality Theory. - Journal of Personality and Social Psychology 38, 375-389.

Orav, Heili; Vainik, Ene 2005. Tee tööd ja näe vaeva, ...aga ikka oled vihane. - Keel ja Kirjandus 4, 257-277.

Orav, Heili 1998. Eesti keele direktiivverbide semantilise välja struktuur tesaurusena. Magistritöö. Tartu Ülikool, üldkeeleteaduse õppetool, käsikiri.

Orav, Heili 2000. Adjektiivid kui semantiline probleem: Wordnet-tüüpi tesauruste koostamise kogemused. - Arvutuslingvistikalt inimesele. Toim T. Hennoste. Tartu Ülikooli üldkeeleteaduse õppetooli toimetised 1. Tartu, 153-166.

Orav, Heili 2002. Adjectives in wordnet-type thesaurus: Estonian experience. - Proceedings of the 1st International Global WordNet Conference, Central Institute of Indian Languages, Mysore, India, 22-25.

Pajupuu, Hille 1994. A nation's autostereotype. - Oral Memory \& National Identity. Papers of the International Conference held in Tallinn, September 18-19, 1993. Tallinn, 31-39.

Pajupuu, Hille 2005. Estonian national stereotypes in transitions. - Cultural Identity in an Intercultural Context. Ed. by D. Petkova, J. Lehtonen. Publications of the Department of Communication 27. University of Jyväskylä, 124-142.

Pükke, Katrin 2005. Liikumise ja paiknemisega seotud verbide semantika arvutirakenduste jaoks. - Bakalaureusetöö. Tartu Ülikool, üldkeeleteaduse õppetool, käsikiri.

Saluveer, Madis; Õim, Haldur 1985. Frames in linguistic description. - Quaderni di Semantica 6, 282-292.

Saluveer, Madis; Õim, Haldur 2002. Freimid keelekirjelduses. - Akadeemia 12, 26632678.

Sutrop, Urmas 2001. List task and a cognitive salience index. - Field Methods 13, 289302.

Õim, Haldur 1974. Semantika. Tallinn: Valgus.

Õim, Haldur 1997. Eesti keele mentaalse maailmapildi allikaid ja piirjooni. - Pühendusteos Huno Rätsepale. Tartu Ülikooli eesti keele õppetooli toimetised 7. Tartu, 255-268. 


\section{SEMANTICS OF PERSONALITY TRAITS}

\section{Heili Orav}

My interest here concentrates on the concepts of personality traits in Estonian. In the case study the author performed interviews among Estonians using the field method to determine active vocabulary of character traits. Results of the experiment are given in this article too. The choice of the character words and concepts that are in active use can give us an idea about the traits which are considered important for the Estonians.

Whereas most common personality traits are expressed by adjectives, I will focus here on the possibilities of analysing them on the conceptual level. I examine most frequent personality adjectives - hard-working, lazy, envious and friendly in accordance with the principles of frame-semantics.

Keywords: frame-semantics, vocabulary of personality traits, field method, adjectives, Estonian

Heili Orav (1969) on Iõpetanud Tartu Ülikooli eesti filoloogia erialal. Kaitses magistrikraadi Tartu Ülikoolis 1998. a üldkeeleteaduse alal, alates 2000. a doktorant. Töötab Tartu Ülikoolis arvutilingvistika teadurina.

heili.orav@ut.ee 